\title{
The Formal and the Relevant: modal underspecification and pragmatic disambiguation
}

\author{
O Formal e o Relevante: subespecificação \\ semântica e desambiguação pragmática
}

\author{
Monica Monawar \\ Claudia Strey *
}

\section{Resumo:}

O objetivo do trabalho é ilustrar uma abordagem semântico-pragmática para a leitura simboulética do modal 'deve'. Para isto, é adotado o modelo de Kratzer (1981, 1991, 2012) para a análise de modalidade em linguagem natural, no qual um modal é relativo à informação contextual via base modal ordenada. A modalidade simboulética de Yanovich (2013a, 2013b), devido à sua natureza inerentemente performativa e mapeamento ainda incipiente, figura nessa ilustração. Diferentemente do modal russo 'stoit' investigado pelo autor, o modal 'deve' do português brasileiro não é exclusivamente simboulético. Portanto, é necessário abordar aspectos de sua subespecificação que permitam uma leitura final simboulética - sendo mais fraca que uma diretiva e mais forte que uma asserção em termos de força performativa. Considerando diferentes contextos, o modal 'deve' parece ser simboulético quando enunciado com prosódia de aconselhamento, mas, quando dito como ordem, aparentemente entraria em colapso com diretivas, alterando a força performativa e derivando uma ORDEM em vez de CONSELHO. A fim de demonstrar como o contexto pode determinar a leitura final do modal, assume-se a perspectiva da Teoria da Relevância (Sperber e Wilson, 1986/1995), que busca explicar como se compreende o significado do falante e, neste caso, como se diferencia um conselho de uma ordem. A distinção entre significado conceitual e procedural, o procedimento de compreensão e a construção de conceitos ad hoc são explorados. Nesse aporte teórico, a prosódia codifica um significado procedural que restringe a leitura final, influenciando a força performativa do verbo modal e construindo um conceito ad hoc.

Palavras-chave: Modalidade; Semântica; Pragmática.

\footnotetext{
* UFSC - I would like to thank CAPES and their National Postdoctoral Program for their support.

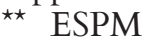


M. Monawar

\& C. Strey

The Formal

and the

Relevant: modal

underspecification

and pragmatic

disambiguation

\section{A BSTRACT:}

The aim of this work is to illustrate a semantic-pragmatic approach to the symbouletic reading of the modal 'deve'. To do so, Kratzer's $(1981,1991,2012)$ framework of analysis for natural language modality is adopted, in which a modal is doubly relative to contextual information via an ordered modal base. Yanovich's (2013a, 2013b) symbouletic modality, due to its inherently performative nature and, considering it is quite new, features in this analysis. Unlike the Russian modal 'stoit', the Brazilian Portuguese modal 'deve'(roughly, 'must' or sometimes 'should') is not exclusively symbouletic. Thus it seems necessary to address the underspecification that allows a successful final symbouletic reading, ranking weaker than directives yet stronger than assertions in terms of its performative force. Considering different contexts of utterance, the same modal verb 'deve' seems to be symbouletic when uttered with a symbouletic prosody, but when uttered with a directive prosody, it appears to collapse, changing the performative force and yielding ORDER instead of ADVICE. In order to demonstrate how context may determine the final modal reading, we assume Sperber and Wilson's (1986/1995, 2003) relevance theory, which aims to explain speaker's meaning, differentiating order from advice. The conceptual-procedural distinction, the relevant-theoretic comprehension procedure and the constructions of ad hoc concepts are explored. In this framework, prosody encodes a procedural meaning which will constrain the proposition expressed, narrowing the performative force and rendering an ad hoc concept.

Keywords: Modality; Semantics; Pragmatics.
Revista Letras,

Curitiba, UFPR, n. 96, pp. 441-460, jul./dez. 2017. ISSN 2236-0999 (versão eletrônica) 


\section{Introduction $^{1}$}

6 What are you doing next weekend?' is a quite normal, mundane question we have all asked and in turn answered a few times in our lifetime. 'Oh, I'm not sure, maybe I'll sleep in if it gets very cold', or 'If you are free, we can do something together' and 'I have papers to grade', are examples of answers deemed natural (thus possible) by any speaker. 'I'll fly to the moon', 'If it rains lava I'll be the Queen of England' are answers that would be, despite their structural soundness, puzzling, to say the least. To the dismay or the joy of linguists, however, the array of possible utterances in natural language does not divide itself in two neat groups instantiated by the examples mentioned before, "possible" or "puzzling". What one deals with is a myriad of possibilities - after all, from a finite set of words we can create an infinite amount of sentences, some that we have never even heard before, thus displaying the creative and recursive aspects of the human language. On top of that, interaction does not make it any simpler.

Let us go back to an interaction everyone has, at one point or another, had with a vending machine. After standing in deep contemplation regarding 1 We would like to thank the anonymous reviewers of this journal for their comments and suggestions, as well as the organizers and attendees of the XI Workshop on Formal Linguistics at the Federal University of Paraná (UFPR) for their contributions. 
M. Monawar

\& C. Strey

The Formal and the

Relevant: modal underspecification and pragmatic disambiguation

the type of beverage or snack to get, a choice was made and, after inserting the appropriate amount of money, the numerical code corresponding to what one wanted was inserted. Thus, voilà, we get exactly what we asked for in that very unequivocal way. Alas, human interaction has never been and will never be so simplistic. In order to communicate with another about something that we wish or want them to do, there are no numerical, one-dimensional codes that cannot be misinterpreted or disputed. Quite the contrary, those who seek interactions so objectively may be often considered inadequate by most of their interlocutors. In this universe of infinite possibilities and interactional complexities, giving someone a suggestion, a piece of advice or an order is not as simple as our interaction with the vending machine. There are aspects related to linguistic structure and meaning in context that need to be accounted for, as well as nonlinguistic aspects that play their part during interaction, like gestures and facial expressions, for instance.

To approach the practice of giving suggestions or advice and orders from all possible angles is an unsurmountable task. Here, we aim to reflect on a possible perspective, focusing on exploring a potential interface between formal and cognitive linguistics in terms of formal semantics and cognitive pragmatics. In order to at the same time illustrate and reflect on this possible interface for the study of the complexities involved in giving suggestions or advice and orders, we address Kratzer's $(1981,1991,2012)$ formal semantic approach to the analysis of modality in natural language and Sperber and Wilson's (1986/1995) relevance theory to the explanation of how context influences meaning.

This paper is organized in the following fashion: first, we illustrate the symbouletic reading of Brazilian Portuguese 'deve' (roughly, 'must' or sometimes 'should') and its potential collapse between suggestion and order due to prosodic interference. Then, in order to expand the argument, the semantics of modality is discussed, following Kratzer's $(1981,1991,2012)$ framework and Yanovich's (2013a, 2013b) proposal for symbouletic modality - concerning suggestion and advice. After that, the pragmatic aspects that come into play in the final reading of symbouletic modality are discussed under the scope of Sperber and Wilson's (1986/1995) relevance theory. At last, final remarks about the illustration are made, considering next steps.

\section{Is that a suggestion or an order?}

Revista Letras,

Curitiba, UFPR, n. 96 , pp. 441-460, jul./dez. 2017. ISSN 2236-0999 (versão eletrônica)
The practices of giving advice, suggestions or orders, as mentioned before, can be encoded in a multitude of ways. These practices vary from one language to another, as well as how the target speech act is encoded in a given occasion. The difference between a piece of advice and an order in English may be, for instance, a lexical choice, when using 'should' instead of 'must'. 
Even so, it would be naive to discuss that as a generality disregarding contextual information altogether.

Moreover, the same difference in terms of lexical choice may be said for Brazilian Portuguese (BP), in which the auxiliary modal 'devia'2 seems to be lexically specified for conveying advice and suggestions (MONAWAR;PIRES DE OLIVEIRA, in prep.). On the other hand, another auxiliary modal, 'deve' does not seem to share the exact same semantic properties as 'devia', allowing other readings depending on the context. Furthermore, we argue here, depending on prosody as well. Thus, a given 'Você deve $x$ ' ('You should/must $x$ ') structure uttered within the same pragmatic constellation (concerning speaker, addressee, their relationship, context, etc.) may, depending on the prosody used, deliver a speech act of ADVICE or one of ORDER. Consequently, the aim here is reiterated, that is, the discussion of how prosody can, in the case of the BP modal 'deve', alter the speech act delivered as an illustration ${ }^{3}$ of a possible interface of analysis for this modal within a semantic-pragmatic perspective.

Symbouletic modality, the modality of advice and suggestion, like any other modal flavor within Kratzer's $(1981,1991,2012)$ framework, relies on contextual information in order to come to its final reading. It requires a metaphysical modal base and a stereotypical ordering source, in which things go as they normally do in the potential worlds closest to the ideal. Inherently performative, this modal flavor, according to Yanovich (2013a, 2013b), has three core features: Decision, that is, the addressee is at liberty to choose $p$ or $\neg p$ since none have yet been actualized; Advice Consistency, one cannot advise both $p$ and $\neg p$, and Performative Force, addressed in more detail in the following 446 section. This last feature is the focus of attention in our discussion, in which we propose that the differentiation of symbouletics and directives (orders) can be signaled via prosody in Brazilian Portuguese symbouletic 'deve'. Following Yanovich's (2013b) proposal that symbouletics may come into collapse when the effective preference of the speaker is that the addressee does what is suggested, we propose that prosodic input ${ }^{4}$ provides pragmatic disambiguation between ADVICE and ORDER in examples like (1) and (2) below.

Assume Laura and Tina meet for coffee and Laura starts complaining that she has been having terrible headaches for a week. Tina is worried about her friend, but she knows Laura always has headaches when she is stressed - which is true, since Laura has to deliver a major speech next week. Tina says to Laura, in an expected symbouletic prosody (1):

2 Considering the aim of this article, the imperfective in 'devia' is not going to be addressed here. Instead, 'devia' and 'deve' are going to be treated as two different modals.

3 The elaboration and discussion of this interface in all of its potential complexities is not within the scope of this work. The aim is to present a possible joint perspective of analysis for this particular phenomenon in Brazilian Portuguese.

4 A phonetic description of these two types of prosodic input is not going to be developed here. Nevertheless, it seems accurate to describe symbouletic prosody as higher pitched than standard in the first, stressed syllable of 'deve'; and directive prosody with an elongated vowel in the same syllable. 
M. Monawar

\& C. STREy

The Formal and the

Relevant: modal underspecification and pragmatic disambiguation

Você deve ir ao médico / You should see a doctor.

[with marked symbouletic prosody, thus ADVICE]

However, consider now a different background. Laura and Tina meet, but this time Laura no longer has to deliver a major speech, she is not stressed, but she has a serious sinus condition. Tina knows, however, that Laura hates taking medicine. At this point, Tina says (2), with directive prosody:

(2) Você deve ir ao médico / You must/have to see a doctor.

[with marked directive prosody, thus ORDER]

Example (2), however, creates an incongruence. Despite the fact that the prosody is marked as directive, the relationship between the speakers does not license an ORDER reading, but rather a symbouletic, ADVICE one. After the exchange, Laura could feel confused and would start looking for an implicature for the clash between what was said and how it was said: Does Tina think she can boss me around? Or is Tina really worried about my health? The list of possible interpretations may vary depending on the previous knowledge about each other, but dissonant inputs will render a incongruent meaning.

Another example illustrates the incongruence that arises when the expected speech act, given the context and the relationship between the interlocutors, is not the one that is ultimately delivered. Consider a situation in which, in order to start working at a company, John needs to undergo physical exams. Linda, in charge of Human Resources, contacts John to let him know that his exams have been scheduled for the following day. She utters (1) and proceeds with the details, rendering John quite confused - why would she be advising him to go, since she is in a position to be telling him to do so? Is this something optional? This confusion signals the contrast due to the use of symbouletic prosody by the speaker. The expected prosody in this case would be a neutral one, leaving the final reading to the propositional and contextual aspects of the utterance.

In order to contrast, consider the same situation, but this time Linda utters (2), ordering John to go take his exams the following day. Again John may be puzzled, seeking to derive an implicature as to why Linda would emphasize it as an order. Adding the fact that there is no possibility to reschedule John's appointment, the directive prosody is then contextually coherent.

These examples suggest that there are complexities involved in the way these contextual cues determine the final modal reading that need to be addressed. In order to explain how prosody interacts with context and how different interpretations are rendered it is important to assume a cognitive view of pragmatics $^{5}$, in this case relevance theory (SPERBER; WILSON, 1986/1995).

Revista Letras,

Curitiba, UFPR, n. 96, pp. 441-460,

jul./dez. 2017. ISSN 2236-0999 (versão eletrônica)
5 The decision to build an interface between formal semantics and cognitive pragmatics is due to the explanatory and descriptive force that arises from the approximation. Other interfaces 
Aiming to explain how communication is processed, relevance theory is seen as a complex proposal to articulate pragmatic theoretical perspectives with recent studies in cognitive psychology. Sperber and Wilson (1995) therefore propose a model of ostensive-inferential communication, postulating two properties that cannot be dissociated: the communicator has to produce an ostensive act, and the audience has to make inferences about the communicator's intentions.

Overall, prosody in BP is an ostensive input that is worth reading, and it seems to communicate not conceptual meaning but rather procedural - which means that prosody guides how conceptual meaning is processed, it indicates the path a specific concept should be processed. Concerning the use of prosody in utterances with modal auxiliaries, symbouletic prosody specifies the modal force of symbouletic modality: it encodes a procedural constraint on the proposition expressed, narrowing the performative force and rendering an ad hoc concept on the explicature, which will only be determined in the context of utterance, as can be seen in (3):

\section{(3) Você DEVE ir ao médico. [You SHOULD/MUST see a doctor.]}

The prosody in BP marks that there is an extra layer of activation that is worth processing because it is ostensive enough. The prosody - symbouletic or directive - indicates which meaning the concept DEVE carries: symbouletic meaning (advice) or directive meaning (order), aside from the standard meaning derived from propositional and contextual information with unmarked prosody. In this sense, incongruent uses of prosody and their clash with context, such as the situations discussed regarding (1) and (2) above, are explained inside the relevant-theoretic comprehension procedure and the conceptual/procedural distinction, yielding the reading as ADVICE or ORDER.

However, before addressing how pragmatics aids in rendering the targeted modal reading in context, it is important to delve a bit more into the semantics of modals.

\section{Symbouletic modality - the modality of advice}

Going back to the very beginning, concerning our plans for next weekend, we will address the chosen object of discussion, that is, modality. When one goes about the different possibilities of plans for the weekend depending on the weather conditions, availability, feelings, etc., one modalizes. This type of displacement - that can co-occur with other types, like temporal or spatial, for instance - takes us from the reference world, normally the real, actual one, into other possible worlds, that represent "[...] many ways things

may be built, but, for the time being, we have decided to bring together these two different sub-areas of Linguistics. 
M. Monawar \& C. STREy

The Formal and the

Relevant: modal underspecification and pragmatic disambiguation

could have been besides the way they actually are" (LEWIS, 1998, p. 96) Modality can thus be said to permeate reasoning regarding plans, conditions, wishes, knowledge, goals, and also suggestions, advice and orders, etc.. After all, when our mothers say "You should eat more vegetables", ultimately they are not referring to the way things actually are, but to how things could (or even, should) be, other possible worlds in which we at least eat more vegetables than we do in the actual one. Comparisons such as this one can also be made between sets of possible worlds, when dealing with competing possibilities, for example: "You should have orange juice or ice tea, it's too hot for coffee today". Thus, through the semantic relations among linguistic expressions, we are sorting out the differences between the sets of possible worlds (KAUFMANN; CONDORAVDI; HARIZANOV, 2006) looking "into the way the human mind deals with inconsistencies” (KRATZER, 2012, p. 1).

\subsection{Kratzer's $(1981,1991,2012)$ framework}

Modality, as a natural language phenomenon, has been studied from several perspectives - be they formal, cognitive or social in nature. Formal approaches have taken much from ideas like the ones put forth by Aristotle - for instance, his discussion of cause and consequence, what may and what cannot be - into many different branches of research. The bridge between the quintessential modal logic approach to modality and its analysis in natural language has largely been built by Kratzer (1981, 1991, 2012).

Kratzer's framework expands on Lewis's (1968) quantificational approach to modals: they quantify over possible worlds. Relative to their context, modal meaning depends on two elements: a modal base, which is a consistent set of facts, and an ordering source, a set of ideals that derives graded modality. In that sense, in a certain context $c$ in which the set of facts, or modal base, is related to speaker's knowledge, one may say the modal base is epistemic. The worlds selected by this epistemic modal base will be organized by the ordering source, which is a set of ideals that may operate based on what normally takes place, on what is moral, etc.

As modality permeates different types of reasoning, there are different types of modality, or modal flavors, i.e., different modal bases and ordering sources yield different readings, different modal flavors. (4) and (5) below are examples of the auxiliary modal 'must' in epistemic and deontic (related to laws, norms) readings:

(4) John must be at work.

[epistemic - based on what the speaker knows about John's routine]

Revista Letras, been adapted or expanded from philosophical traditions.

Curitiba, UFPR, n. 96, pp. 441-460,

jul./dez. 2017. ISSN 2236-0999 (versão eletrônica) 
These two examples of 'must' consist of different readings of the same auxiliary modal, which have been achieved by contextual restriction of the scope of quantification it has over possible worlds. Von Fintel (2006, p. 4) summarizes:

Epistemic modality has an epistemic modal base and either no ordering or an ordering based on plausibility or stereotypicality. Deontic modality has a circumstantial modal base (because one may have to abstract away from one's knowledge that the right thing will not be done) and an ordering source based on a body of law or principles. Bouletic modality again has a circumstantial modal base and an ordering source based on a relevant person's desires. And so on.

This double relativity of modals (according to their modal base and ordering source) yields, contextually, the final modal reading in terms of its modal force as well. Concerning modal force, Kratzer (2012) affirms that, differently from the logical perspective in which necessity and possibility can be considered duals, there are instances or even languages in which this duality does not occur, resulting not in modals of necessity or possibility, but degree expressions of desirability or probability. In Brazilian Portuguese, according to Pessotto (2014), this takes place with the modal 'dever' (must/should), as it can be placed on a high end of a desirability/probability scale, while 'poder' (might/may/can) lies on a lower point of the same scale. Considering therefore an epistemic modal base and a stereotypical ordering source, different degrees of modal force are yielded depending on the modal used. For example, it seems rather unequivocal to judge "Deve chover amanhâ" ("It must/should rain tomorrow") stronger than "Pode chover amanhã" ("It might/may rain tomorrow"). This difference in force, one must remember, is ultimately provided by context via the modal base and the ordering source.

Finally, Kratzer's double relativization of modals aims to account for modal underspecification - a hazy 'must' would only be so because its sentential context did not provide enough information for its relativization, what needs to be accomplished by other contextual cues sought by the interlocutors. As modals can be descriptive/static or performative (KAUFMANN, 2012), our concern here is to address performative modality, more specifically the modal flavor of suggestions and advice, and the contextual clues that relativize the modal and determine its final reading and their effects on the resulting performative force in terms of the speech acts of ADVICE or ORDER. 
M. Monawar

\& C. STREY

The Formal and the

Relevant: modal underspecification and pragmatic disambiguation

\subsection{Symbouletic Modality}

Differently from other modal flavors that are static or some that may also be used performatively (deontic modality, for example), symbouletic modality is, in essence, performative. That means it does not have instantiations of nonperformative use, relying heavily on interaction. Coined 'symbouletic' by Paul Kiparsky and developed by Igor Yanovich (2013a, 2013b), this new modal flavor constitutes itself precisely on the hinges that make up the articulation of the interfaces, here being semantics and pragmatics.

Nevertheless, not unlike other modal flavors, symbouletic modality is doubly relative. According to Yanovich (2013a, p. 11), this modal flavor is relative to a metaphysical modal base and a stereotypical ordering source, so that:

$$
\begin{aligned}
& y \text { has control over } p \text { at an index } i \text { among stereotypically optimal } \\
& \text { worlds among the metaphysically accessible worlds at index } i \text {, } \\
& \text { there are p-worlds and } \neg \text { p-worlds, and furthermore, there are } \\
& \text { actions available to y that bring about } \mathrm{p} \text {, and similarly for } \neg \mathrm{p} \text {. }
\end{aligned}
$$

Thus, when one says "You should go to that concert", the addressee is presupposed as having control over achieving $p$, in this case, going to the concert. The assertion present is that it is in some way beneficial for the addressee to go and, because of that, they should develop or have an effective preference ${ }^{7}$ (EP) towards $p$. The core of effective preference in contrast of simply having a preference is that action is involved. I can prefer waking up early than late, but if I have an effective preference for waking up early, I will make sure I am up and running whenever 'early' is. So, when I say "You should go to that concert", I am at least hoping that the addressee will develop an effective preference towards going to the said concert perhaps because I deem it to be beneficial for them in some way. Summing up, Decision, that is, the addressee's control over proceeding to $p$ or even $\neg p$ if they choose, Performative Force, related to guiding the addressee's actions via their effective preference, and Advice Consistency, meaning that one cannot advise both $p$ and $\neg p$, are the core ${ }^{8}$ features of symbouletic modality. For the purposes of this work the feature of Performative Force is going to be addressed here.

It has been said that symbouletic modality is inherently performative. That refers to the notion that it guides actions, patterning itself with imperatives (YANOVICH, 2013b). Yanovich (2013a, 2013b) describes the Russian modal

7 The notion of effective preference $(E P)$ is not addressed here due to the scope of the discussion. See Yanovich (2013a) for details concerning EP and symbouletic modality and Condoravdi and Lauer $(2011,2012)$ for its proposal.

8 Addressee benefit is not considered by Yanovich (2013a) a core feature of symbouletic modality because English 'should' and Russian 'nužno' can be used for suggestions that do not involve addressee benefit, like in "You should be quiet now". For a thorough approach to other features of symbouletic modality the reader is referred to Yanovich (2013a, 2013b).
Revista Letras,

Curitiba, UFPR, n. 96, pp. 441-460,

jul./dez. 2017. ISSN 2236-0999 (versão eletrônica) 
auxiliary 'stoit' that, unlike English 'should', is exclusively symbouletic, and proposes its formal analysis as below (YANOVICH, 2013b, p. 22):

(i) $\operatorname{stoit}(x, p)$

presupposes decision $(x, p)$

asserts best $(x, p) \Lambda$ advise $(S U, x, p)$, where $S U$ (from SUggest-er) is the

subject in a matrix context, and the attitude bearer under attitudes

Considering the formal analysis of 'stoit', the author proposes the formalization of 'advise', including EP (YANOVICH, 2013b, p. 24):

(ii) advise $(S U, x, p)$

$E P\left(S U, \Lambda_{q} \operatorname{best}(x, q)\right) \rightarrow E P(S U, E P(x, p))$

The formalization above can be paraphrased the following way: "If your interests were the most important thing for me, I would have tried my best to get you do $p$ " (YANOVICH, 2013b, p. 25). This follows Condoravdi and Lauer's (2011) formalizations of EP in other performative situations, like commissives and directives. What would, then, be the relationship between symbouletic modality and these other EP-based meanings? Yanovich (2013b, p. 27) claims that symbouletics are weaker than directives, and may give rise to scalar inferences - if one used a symbouletic, then a directive would have been too strong, even though the author acknowledges situations where they may collapse, such as when the speaker has an EP about what the addressee 452 does. Then, technically, symbouletics are stronger than simply asserting what would be good for $y$ to do, and at the same time weaker than a directive - the author argues that they are conditional directives (YANOVICH, 2013a). This clean-cut scale cannot always be thus addressed, and the analysis of symbouletics grows more and more complex when the modal under analysis is not exclusive to this type of reading, as is the case of the non-dual Brazilian Portuguese (BP) modal auxiliary 'deve' (it can roughly be translated into 'must' or even 'should', a matter discussed in Strey and Monawar (in press)).

As mentioned before, following Kratzer (2012), not all modals have duals, that is, some can be degree expressions that belong to the upper end of a scale. According to Pessotto (2014), that is the case for BP 'dever', a modal auxiliary that can have different readings, as in the examples below:

(6) Você deve votar / You must vote.

[deontic - according to the law]

(7) Você deve ser a Ana / You must be Ana.

[epistemic - based on knowledge and evidence] 
M. Monawar

\& C. Strey

The Formal and the

Relevant: modal underspecification and pragmatic disambiguation
(8) Você deve pegar o trem amarelo / You should take the yellow train. [teleological - considering goals]

(9) Você deve ir ao médico / You should see a doctor [symbouletic - guiding the addressee's actions for their benefit]

Other readings of 'deve' are possible, but they are not our focus here. The aim of the examples above is to illustrate different instantiations of 'deve' in different readings due to different contextual information that has restricted the modal via its modal base and ordering source. In (6), the modal scopes over a set of worlds that is metaphysical, those in which the addressee goes to the doctor, and orders them as things normally happen, according to the ideal that the addressee will comply and have the EP to go see a doctor. So far so good, right? In interaction, however, a few issues arise.

We have elsewhere discussed that BP prosody can perform alterations in the final reading of the modal in terms of its modal force (MONAWAR;STREY, 2014). When it comes to the symbouletic reading of this modal, prosody can alter the final modal reading and, consequently, its performative force, causing the collapse between symbouletics and directives discussed before. It is due to this possibility that the analysis of 'deve' in BP symbouletic modality may give way to a better understanding of how contextual cues contribute to the final modal reading and the delivered speech act. With that in mind, the following section deals with the pragmatics that comes into play.

\section{The pragmatics of prosody}

The shades of communication have been the main object of pragmatics, whose definition itself is too vague and too general. Defined as the study of language in communication, its boundaries are blurred, as it can be related and influenced by different disciplines. Broadly speaking, the study of propositional or linguistic meaning is the domain of semantics, and the study of utterance or speaker meaning is the domain of pragmatics. Assuming that speaker meaning involves cognitive machinery, pragmatics has its roots in the cognitive sciences and explains how cognitive processes are involved in intentional verbal and nonverbal communication (HUANG, 2012). That said, relevance theory comes up as an alternative to take one step further in the description and explanation of human communication.

\subsection{Relevance theory framework}

Sperber and Wilson's (1986/1995) relevance theory is concerned with the establishment of a cognitive principle to explain the inferential process of human
Revista Letras,

Curitiba, UFPR, n. 96, pp. 441-460, jul./dez. 2017. ISSN 2236-0999 (versão eletrônica) 
communication. To understand what has been ostensively produced, the hearer has to recover the linguistically encoded sentence meaning, which is contextually enriched to yield the speaker's meaning. There are different processes that take place at this time, such as resolution of ambiguity and referential ambivalences, interpretation of ellipses, identification of implicatures, resolution of illocutionary indeterminacies, interpretation of metaphors and ironies, and underdeterminacy of explicit content that may be present (WILSON; SPERBER, 2004). Finally, according to relevance theory, the resolution of a fully fledged speaker's meaning requires a set of contextual assumptions.

In order to explain how the audience understands the speaker, Wilson and Sperber (2004, p. 259) suggest that the hearer follows a procedure to perform those subtasks and builds a hypothesis about the speaker's meaning:

\section{(i) Relevance-theoretic comprehension procedure:}

(a) Follow a path of least effort in computing cognitive effects: Test interpretive hypotheses (disambiguations, reference resolutions, implicatures, etc.) in order of accessibility;

(b) Stop when your expectations of relevance are satisfied.

The theory foresees that the inferential process happens on both explicit and implicit levels, treating the identification of explicit context as inferential as the implicit one. Relevance theory bets on the existence of an intermediate level between what is said and what is implied: the explicature - which is a communicated proposition recovered by a combination of decoding and 454 inference, and that works as a premise to derive contextual implications and other cognitive effects (SPERBER; WILSON, 1986/1995). The explicature involves a basic level - the enrichment of the logical form - and a higher-level, which requires more pragmatic development such as determining the propositional attitude or embedding the basic proposition into a speech act. Various pragmatic operations take place in the explicature, such as the determination of the final reading of a modal and the resulting performative force.

On this account, the construction of both explicature and implicature is a result of a process of mutual parallel adjustment, and the hypothesis about speaker's meaning is considered in order of accessibility. During the comprehension process, some words present in the explicature are adjusted according to the context in which they occur, and they are derived as ad hoc concepts (CARSTON, 2002). According to Wilson and Carston (2006), each time a concept is communicated, it is automatically adjusted through an online process to form the explicature. Once adjusted, through restrictions or extensions, the ad hoc concept is created and the inferential process continues through the construction of implicatures?.

9 It is important to note that the construction of both explicatures and implicatures are made online and in parallel. The sub-tasks of interpretation are not sequentially ordered, but developed against a background of hypotheses that may be re-elaborated as the communication unfolds (WILSON; SPERBER, 2004). 
M. Monawar

\& C. STREy

The Formal and the

Relevant: modal underspecification and pragmatic disambiguation

On the presumption that the speaker is aiming at optimal relevance, they will test in context the most accessible meaning to see whether it achieves sufficient cognitive effects. If, when processed in context, this interpretation provides enough cognitive effects for the effort invested, the hearer would take it to be the one the speaker intended; if not, they look again. According to Wilson (2012), the existence of ad hoc concepts may allow the treatment of more abstract cases. For example, scalar terms such as tall and short may be seen as encoding the same conceptual information (localization on a height scale), but different procedural orientation: tall indicates that one moved up the height scale, and short that one moved down the height scale.

\subsection{Conceptual and procedural meaning}

Assuming a relevance-driven theory of pragmatics (SPERBER; WILSON, 1995, 2012), Blakemore $(1987,2002)$ stated a difference between content words (e.g. 'cat') and procedural words (e.g. 'therefore'). The first are seen to encode concepts that contribute to the truth-conditions of a sentence, such as 'dog', while the latter carry a non-truth conditional meaning, guiding the inferential comprehension process, e.g. 'therefore'. The procedural idea is inherently pragmatic, as Bezuidenhout (2004, p.1) posits:

Something that lies on the procedural side of the procedural/ declarative divide is something inherently pragmatic that belongs to a performance system, and is distinct from the knowledge that is constitutive of a speaker-hearer's semantic competence.

According to Wilson (2012), procedural expressions correspond to states of language users. In this sense, a procedural expression may activate or trigger procedures already available to the hearer, being hard to pin down in conceptual terms and appearing in different types and forms. Procedural meaning is not only found in specific classes of words such as conjunctions; it is also present in other nonverbal inputs such as prosody. Wilson (2012) proposes we find clusters of procedural items (interjections, attitudinal particles, intonation) linked to emotion reading (WHARTON; STREY, in press) and to mindreading(BARONCOHEN, 1995). The author also says procedural meaning can be found in different parts of discourse, such as punctuation, prosody, and discourse particles, guiding the comprehension process in one direction or another. Observe the effect of prosody on the interpretation of "Sue has money". If the word 'money' is stressed, it may guide the inferential process to imply that Sue not only has

Revista Letras,

Curitiba, UFPR, n. 96 , pp. 441-460,

jul./dez. 2017. ISSN 2236-0999 (versão eletrônica) 
money but she has a lot of money. Wharton (2009) describes prosodic inputs as highly context-dependent, because they interact with information from other sources, and they may have different effects depending on the occasion. The author (WHARTON, 2009, p. 141) posits that a general point of agreement in the literature is that

prosody typically creates impressions, conveys information about emotions or attitudes, or alters the salience of linguistically possible interpretations rather than expressing full propositions or concepts in its own right.

Procedural meaning, hence, constrains the search for relevance, narrowing the range of hypotheses and constraining both the explicature and the implicatures derived. House (2006) says that prosody can be best described as forming the packaging rather than the content of a message. It has multiple functions: directly encoding the type of cognitive effect intended; constraining the context, orienting the hearer to access a particular set of assumptions, setting procedural constraints on explicit content.

When a marked prosody is inserted in a neutral utterance, it is interpreted as a relevant input, which is worth processing in a context of available assumptions to yield positive cognitive effects. It will encode procedures to constrain what is being conceptually communicated. Consider example (10), where Mary meets her son Jack, who is feeling cramps after running a half marathon. Mary says to Jack, stressing the word 'deve' with directive prosody.

(10) Mary: Você DEVE comer mais banana. (You MUST eat more banana).

Following a path of least effort in looking for enough cognitive effects, "the more salient the prosodic input, the more it will be expected to contribute to the speaker's meaning by achieving positive cognitive effects" (WILSON; WHARTON, 2005, p. 442). In example (10), when produced with directive prosody, it would increase the hearer's phonological processing effort, but at the same time it would encourage them to look for extra effects. The concept DEVE therefore would be adjusted during the recovery of the explicature, rendering the concept DEVE ${ }^{\star}$ with directive meaning. (11) is a schematic outline of how Jack might use the relevance-theoretic comprehension procedure to construct a hypothesis about the explicature of Mary's utterance:

(a) Mary said to Jack, 'Você $\hat{x}_{\mathrm{x}} \mathrm{DEVE}^{\star} / \mathrm{DEVE}^{\star \star}$ comer mais banana.'

[Você ${ }_{\mathrm{x}}=$ Jack]

$\left[\operatorname{DEVE}^{\star}=\right.$ advice reading]

$\left[\mathrm{DEVE}^{\star \star}=\right.$ order reading $]$ 
M. Monawar

\& C. Strey

The Formal and the

Relevant: modal underspecification and pragmatic disambiguation

(b) Mary's utterance will be optimally relevant to Jack.

(c) Mary's utterance will achieve relevance by explaining that bananas are good for cramps.

(d) Mary's directive prosody indicates that the utterance is an order.

(d) Explicature: Jack DEVE ${ }^{\star \star}$ (HAVE/MUST) eat more bananas.

In (11), the hearer assumes that the encoded word meaning and the marked prosody are clues to the speaker's meaning. Guided by expectations of relevance and using the available contextual assumptions, Jack starts deriving cognitive effects. When there are enough effects to satisfy his expectations of relevance, he stops. The result is that the explicature (11d) contain not the encoded concept DEVE but the ad hoc concept DEVE ${ }^{\star \star}$, with a different denotation. If (11) was uttered with a neutral prosody, it would not be processed as a relevant input; therefore it would not activate an extra layer of cognitive effort.

To account for meaning in context implies bringing into the game different aspects of communication. The vending machine situation is an example of the code model of communication: a message is first coded then decoded. I want water, so I press the right buttons - encoding the message; the machine will give me water - decoding what I communicate. There is not a lot of space for anything that falls out of the given rules of the game. However, this is not always the case when we communicate: sometimes an order seems like an advice, and vice-versa. And it depends on different cues, like prosody as has been here shown. In order to explain how we mean more than what we say, it seems necessary to have a model that explains how we produce different inferences depending on the given context.

\section{Final remarks}

The aim of this work was to illustrate a possible semantic-pragmatic approach to symbouletic modality in terms of the contributions of prosodic input in ADVICE and ORDER speech acts derived from utterances with the BP modal 'deve'. To do so, we have discussed Kratzer's $(1981,1991,2012)$ framework of analysis for natural language modality, in which a modal is doubly relative to contextual information via a modal base and an ordering source. In addition, Yanovich's (2013a, 2013b) symbouletic modality was chosen its inherently performative nature and, considering it is quite new, still widely uncharted territory.

The Brazilian Portuguese auxiliary modal 'deve', unlike the Russian 'stoit', does not seem to be exclusively symbouletic, thus its underspecification must be dealt with in order to discuss when one obtains a successful final symbouletic

Revista Letras,

Curitiba, UFPR, n. 96, pp. 441-460, jul./dez. 2017. ISSN 2236-0999 (versão eletrônica) 
reading, ranking weaker than directives yet stronger than assertions in terms of its performative force. This modal, when uttered with marked directive prosody, appears to collapse with directives, changing the performative force and yielding ORDER instead of ADVICE. On the other hand, it seems to yield ADVICE when uttered with marked symbouletic prosody. We have discussed that this is perhaps a way of signaling the speaker's effective preferences in relation to what is being said and what they want the addressee to do. In order to address how these contextual cues act in the pragmatic disambiguation, we have worked from the perspective of Sperber and Wilson's (1986/1995) relevance theory and its articulations of conceptual and procedural meaning in the arriving of the explicature and implicatures.

Further theoretical and experimental research is needed in order to fully elaborate and commit to the proposal sketched here, especially in terms of testing native speakers' reactions to incongruent settings of contexts and marked prosody like the ones mentioned regarding examples (1) and (2). Nevertheless, this work has accomplished its aim, to illustrate the possible interface and discuss the contributions of both semantics and pragmatics to the analysis of this phenomenon in natural language. 
M. Monawar

\& C. STREy

The Formal

and the

Relevant: modal

underspecification

and pragmatic

disambiguation

\section{References}

BARON-COHEN, S. Mindblindness. Cambridge, MA: MIT Press, 1995.

BEZUIDENHOUT, A. Procedural meaning and the semantics/pragmatics interface. In: Bianchi, C. (Ed.) The Semantics/Pragmatics Distinction. Stanford, CA: CSLI, 2004. p. 101-131.

BLAKEMORE, D. Relevance and Linguistic Meaning. Cambridge University Press, 2002. Semantic Constraints on Relevance. Oxford: Blackwell, 1987.

CARSTON, R. Linguistic meaning, communicated meaning and cognitive pragmatics. Mind \& Language, v. 17, p. 127-48, 2002.

CONDORAVDI, C.; LAUER, S. Performative verbs and performative acts. In: REICH, I.; HORCH, E.; PAULY, D. (Eds.). Sinn und Bedeutung 15: Proceedings of the 2010 annual conference of the Gesellschaft fur Semantik. Saarbrucken: Universaar I Saarland University Press, 2011. p. 149-164.

Imperatives: meaning and illocutionary force. In: PIÑÓN, C. (Ed.). Empirical Issues in Syntax and Semantics 9, 2012. p. 37-58.

HOUSE, J. Constructing a context with intonation. Journal of Pragmatics, v. 38, n. 10), p. 1542-1548, 2006.

HUANG, Y. The Oxford Dictionary of Pragmatics. Oxford: Oxford University Press, 2012.

KAUFMANN, S.; CONDORAVDI, C.; HARIZANOV, V. Formal Approaches to Modality. In: FRAWLEY, W. The Expression of Modality. Berlin: De Gruyter Mouton, 2006. p. 72-106.

KAUFMANN, M. Interpreting Imperatives. Berlin: Springer, 2012.

KRATZER, A. The Notional Category of Modality. In: EIKMEYER, H. J.; RIESER, H. Words, Worlds, and Contexts. Berlin and New York: de Gruyter, 1981.

Modality. In: STECHOW, Av.; UNDERLICH, D. Semantik. Berlin and New York: de Gruyter, 1991.

Modals and Conditionals. Oxford: Oxford University Press, 2012.

LEWIS, D. Counterpart Theory and Quantified Modal Logic. Journal of Philosophy, v. 65, n. 5, p. 113-26, 1968. 549-67, 1996.

Elusive Knowledge. Australian Journal of Philosophy, v. 74, n. 4, p.

Revista Letras,

Curitiba, UFPR, n. 96 , pp. 441-460,

jul./dez. 2017. ISSN 2236-0999

(versão eletrônica) 
MONAWAR, M. Modality and evidentiality: a discussion of philosophical and formal aspects. Letras de Hoje, v. 51, n. 3. Porto Alegre: EDIPUCRS, p. 412-20, 2016.

MONAWAR, M.; PIRES DE OLIVEIRA, R. (in prep.). The semantics of advice: a study on 'devia'.

MONAWAR, M.; STREY, C.. The interference of prosody in interpretation of symbouletic modality: a study of Brazilian Portuguese. In: MADA, S.; BUJA, E. (Eds.). Structure, Use, and Meaning in Intercultural Settings.1 ed. Brasov : Editura Universitatii Transilvania, 2014. p. 169-180.

PESSOTTO, A. Epistemic and Gradable Modality in Brazilian Portuguese: a comparative analysis of 'poder', 'dever' and 'tem que'. ReVEL, special issue 8 , p. 49-75, 2014.

SPERBER, D.; WILSON, D. Relevance: Communication and Cognition. Oxford: Blackwell, 1995.

STREY, C.; MONAWAR, M. (in press). Grammatical and Communicative Competence as one: a study on symbouletic modality.

VON FINTEL, K. Modality and Language. In: BORCHERT, D. M. (Ed.). Encyclopedia of Philosophy - Second Edition. Detroit: MacMillan Reference USA, 2006. Available at: http://web.mit.edu/fintel/modality.pdf

WHARTON, T. Pragmatics and Non-Verbal Communication. Cambridge: Cambridge University Press, 2009.

460 WILSON, D. Modality and the conceptual-procedural distinction. In: WALASZEWSKA, E.; PISKORSKA, A. (Eds.). Relevance Theory. More than Understanding.. New Castle upon Tyne: Cambridge Scholars Publishing, 2012.

WILSON, D; SPERBER, D. Linguistic form and relevance. Lingua, v. 1, n. 90, p. 1-25, 1993.

Relevance Theory. In HORN, L.R.; WARD, G. (Eds.). The Handbook of Pragmatics. Oxford: Blackwell, 2004.

WILSON, D.; CARSTON, A. A unitary approach to lexical pragmatics: relevance, Pragmatics. Basingstoke: Palgrave Mauage. v. 21, n. 3, 2006.

WILSON, D.; WHARTON, T. Relevance and prosody. UCL Working Papers in Linguistics, v. 17, p. 427-454, 2005.

YANOVICH, I. On Advice Modality. Los Angeles: UCLA, 2013a.

. Symbouletic Modality. In: COLLOQUE DE SYNTAXE ET

SÉMANTIQUE À PARIS (CSSP), 10., 2013, Paris. Proceedings Empirical Issues 10. Paris: CNRS, 2013b. p. 161-178.

Submetido em: 07-03-2017

Aceito em: 13-07-2017 